\title{
Beyond Classical Definition: The Non-definition of Gamification
}

\author{
Mario S. Staller ${ }^{1}\left[\right.$ Swen Koerner ${ }^{2}$ \\ Received: 12 November 2020 / Accepted: 16 January 2021 / Published online: 10 February 2021 \\ (c) The Author(s) 2021
}

\begin{abstract}
Gamification is regularly defined as the use of game elements in non-gaming contexts. However, discussions in the context of the pedagogical value of gamification suggest controversies on various levels. While on the one hand, the potential is seen in the design of joyful learning environments, critics point out the pedagogical dangers or the problems related to optimizing working life. It becomes apparent that the assumptions guiding action on the subject matter of gamification in educational contexts differ, which leads to different derivations for pedagogical practice-but also allows for different perspectives on initially controversial positions. Being aware of these assumptions is the claim of a reflexive pedagogy. With regard to the pedagogical use of gamifying elements and their empirical investigation, there are three main anchor points to consider from a reflexive stance: (a) the high context-specificity of the teaching undertaken and (b) the (non-)visibility of the design elements and (c) the (non-)acceptance of the gamified elements by the students. We start by providing a discussion of the definitional discourse on what is understood as gamification leading to our argument for a non-definition of gamification. We describe the potential of this non-definition of gamification and exemplify its use in a gamified concept of teaching police recruits professional reflexivity. The concept features the narrative of a potential crime that has been undertaken and that students decide for themselves if they want to engage with it.
\end{abstract}

Keywords Gamification · Non-definition · Learning environment

\section{Introduction}

Playing is part of human nature [10, 24]. Playing is fun, motivating and engaging $[41,46,66]$, promotes competition [46] and has a positive effect on teamwork [64]. In addition, playing games is also suitable for trying out behavioral strategies and can thus serve as a consistently reduced training and educational environment [57]. Our private and

This article is part of the topical collection "Cyber Security and Privacy in Communication Networks" guest edited by Rajiv Misra, R K Shyamsunder, Alexiei Dingli, Natalie Denk, Omer Rana, Alexander Pfeiffer, Ashok Patel and Nishtha Kesswani.

Mario S. Staller

mario.staller@hspv.nrw.de

Swen Koerner

koerner@dshs-koeln.de

1 Department of Police, University of Applied Sciences of Police and Public Administration North RhineWestphalia, Aachen, Germany

2 Department of Training Pedagogy and Martial Research, German Sports University, Cologne, Germany professional lives seem to be permeated by gamified elements, for example, when collecting bonus points when shopping, in the context of health care or when traveling $[55,60]$. Gamified activities primarily aim to increase motivation in a wide variety of activities to increase the quantity and quality of the output of the corresponding activity [42]. The idea seems simple: the joyful and motivating aspects of the game should be used to positively influence less joyful and motivating activities, such as routine activities, in the sense of a better output [45]. The goal is to take advantage of the positive aspects of playing and to transfer them into non-playful contexts. The instrumental use of these design elements, through which the transfer of the positive qualities of games should take place, is generally understood as gamification [16]. However, a consensual definition is still lacking $[43,52]$. For example, other definitions focus on the utilitarian benefits of gamification: gamification as process improvement through playful elements to increase value creation $[19,26,59]$ or nudge participants to perform certain actions [43]. While the definition of Deterding et al. [16] includes the use of game design elements without direct transfer to an improved output (e.g. higher motivation, more 
performance), this is a mandatory prerequisite for the intention of gamification in the definitions of Huotari et al. (2012) and Pfeiffer et al. [43]. The utilitarian perspective of gamification is of particular interest in educational contexts $[8,9$, $14,44,61]$, but there are also critical perspectives on its use in these contexts $[7,68]$.

Empirical studies on possible positive effects of gamification show a mixed picture. An explanatory approach for the different results lies in the range of possibilities for gamification (e.g. points, levels, narrative elements) and their application in different contexts with different user groups $[25,52]$.

While much of the empirical data on gamification examine its immediate benefits $[19,25,36]$, the question arises to what extent the experience of gamification per se can represent a value that does not necessarily manifest itself in behavioral change. Normatively, it is regularly stated that gamification should not impair the effectiveness of an educational setting (operationalized as learning that has taken place) [18]. However, to what extent a gamification must have positive effects on behavior, we consider worthy of discussion. Does something have to be achieved/changed or can the experience (through a gamified element) per se also be desirable? It is precisely here that the difference between different conceptualizations of gamification unfolds its effects.

We argue in this article that the different concepts of gamification lead to controversies on various levels. While on the one hand, the potential is seen in the design of joyful learning environments [25], critics point out the pedagogical dangers [7] or the problems related to optimizing working life [68].

We argue, that these different perspectives are mainly related to differing guiding assumptions about the core of gamification, which in turn lead to different derivations for pedagogical practices. Being aware of these assumptions allows for new perspectives of initially controversial positions. Being aware of these assumptions is the claim of reflexive pedagogy $[6,29]$, taking a reflexive stance towards what is implemented how and why in specific contexts.

Therefore-the current paper aims at reflecting the assumptions about gamification and proposes a non-definition of gamification that can guide implementation from a reflexive standpoint harnessing its context-specificity. To explain our point, we conclude by presenting a gamified learning environment that has been conducted at a German Police University and that has been evaluated elsewhere [56].

\section{Definitional Discourse: What is Gamification?}

Language allows us to differentiate between different concepts. Viewed from a system's theoretical perspective, the assignment of a term towards a phenomenon A distinguishes it from what is not: not-A [37]. As such gaming has been differentiated from play and play from not-play [65]: a game is not a play, and playing is not not-playing. Concerning the difference between game and play, there are languages that do not differentiate between these two concepts. For example, in German, there is no difference between game and play. Germans use the term "Spiel". Germans "spielen"-without considering further differentiations of this term (like play and game) on a linguistic level. As such, for Germans, gaming is playing and gaming is playing ("spielen ist spielen"). While one may wonder, why the aspect of non-differentiating between these concepts may be of value, we have to consider the conceptualizations of gamification, which relates to the difference between play and game. If there are different framing assumptions of what may be included within the concept of gamification, the result of what gamification in educational contexts (and others as well) looks like will likely differ. The focus on what is understood to be used excludes what is not focused upon. The definition limits its practical use.

Turning to the different conceptualizations of gamification, Deterding et al. [16] define gamification as the use of game design elements in non-game contexts [16], whereby the authors limit gamification to "games" and not "play". This is an important point based on Caillois' [10] distinction between "paidia" (playing) and "ludus" (gaming), where paidia demarcates a more anarchic mode of spontaneous interaction against the structured competition of ludus. The difference between these two concepts (play vs. game) is regularly discussed [65] and has implications for the concept of gamification [68]. Woodcook et al. (2018), for example, state the human desire for play (more closely paidia than ludus) as the reason for the enormous difficulties in analyzing gamification. A game is often ascribed a higher structure on several levels than a play $[10,28,65]$.

These structural characteristics of a game are criticized from an educational perspective, since-according to the argumentation-it is characterized by linearity and thus offers no platform for "applying pedagogical-reflexive power of judgement" [7] (p. 276). Based on the assumption of a temporal and spatial framework of a game, this argumentation seems plausible. Buck [7] continues that "Players [...] cannot transcend the rules of the game and the rules set beforehand, they are subject to a set of conditions that categorically exclude the participation, contradictions or even participation and modification of the 
regulator" (p. 277). This argumentation of structural containment and the resulting limited framework for action is also shared by other authors [68]. The structures given by rules and mechanics in the game undoubtedly limit, on the other hand, however, they also allow degrees of freedom that can be developed on a functional level [30,63]. This is, for example, where non-linear pedagogy shows its potential [30]: It uses the setting of constraints in order for more freedom to emerge. In addition to the potential of limitation to open up more potential for freedom, however, the basic assumption of the pre-structuring and linearity of play also seems worthy of reflection.

In practice, it becomes clear that what is played is not always a structured game. Even within the structural game frame, players find joyful activities beyond the designer's intention and beyond the intended structure [65]. In various video game formats, the structural framework becomes blurred, which becomes clear in the example of open-world video games (e.g. Red Dead Redemption 2). There is no rigid linearity.

Irrespective of the differentiation between game and play, it is not always easy to distinguish between play and noplay [65]. Although [24] in his seminal work "Homo ludens" points to the spatial and temporal limits as a constitutive moment of play, it is evident from the playful practices, such as Alternate Reality Games [12, 38, 41] that this spatial and temporal structuring can be perpetuated. The question of whether a game has already begun can also be a question of perspective. To know that one is part of a game, the player would have to recognize that he/she is playing, which in turn raises the question of recognizing the state of play.

From a practical point of view, for example, it is possible to involve students in a game without noticing them immediately. The teacher (or puppet master in the jargon of Alternate Reality Games) is playing the game, but from the perspective of the players, this is not necessarily directly recognizable or there is also the possibility of refusing access to the game. In this case, the teacher plays but not the learner. On the other hand, it is possible that a learning setting is perceived as a "game" by a learner or is redefined as such, even if the teacher would vehemently deny this. There seems to be a certain subjectivity in the concept of play: it plays, who plays.

Sutton-Smith [62] argues in a similar direction. He argues that the definition of both play and game in positive, nonparadoxical terms is a hopeless endeavor. Instead, he suggests the use of clear examples when referring to play or game, which in turn has a subjective character. It seems like we cannot escape our paradigmatic horizon, since our observations are entangled in our understanding of the observed itself [62]. Sutton-Smith goes on to say that in terms of action and epistemology, we are so burdened by the game that it becomes a paradoxical task to go beyond this framework and view the game in a neutral and ontological way. It becomes apparent that it is difficult to differentiate between the two concepts (play vs. game) - and also in the differentiation from what is called non-game-and that the transitions are fluid [28, 62, 65]. Accordingly, various authors point out the transgressive character of the individual concepts $[65,68]$.

The blurring character of a conceptualization of game is evident in the Alternate Reality Games mentioned above. Their character is described as difficult to define and the design also shows that the boundaries blur. This is already evident in the immanent game principle of Alternate Reality Games: "This is not a game"— the game as a non-game. If non-game, game, non-play and play cannot always be clearly separated, what does this mean for the use of game elements in non-game contexts? Is this subjective perspective on what is understood as play also the case with the use of game elements in non-game contexts? Woodcock and Johnson [68] argue in that direction. They describe the playful subversion of working life, which they refer to as gamification-from-below, as the "true" form of gamification. In contrast, they refer to the application of a specific game mechanic to everyday life as gamification-from-above with a primary focus on the reinforcement of work. This "terminological foreclosing of alternative possibilities" (p. 12) restricts gamification to the linear-framed boundaries with its critiques [4, 7]. By understanding gamification beyond a limiting structural framework of a playful experience beyond primarily intended playing settings, it releases its full potential. It plays, who plays. The definition as a non-definition.

\section{The Potential of a Non-definition of Gamification}

With regard to teaching practice, the definitional discourses only help to the extent that they enable reflection on the own action-guiding assumptions of the own (gamified) teaching practice. From a practical perspective, the question seems to be rather whether and how gamification (in the sense of nondefinition) can make a contribution in educational settings.

The literature on gamification refers-in view of a non-consensual gamification theory $[18,40]$ - to different theories and concepts of psychology, which play a role in connection with different design elements [23, 47, 51]. For example, the concept of self-efficacy $[2,3]$, the needs of Maslow [39], goal setting theory [33-35], the theory of social comparison [17], flow theory [15, 54] and last but not least, self-determination theory [50]. The latter in particular is used as a meta-theory to motivate the effects of many game elements as an explanatory approach $[48,49]$. The instrumental character of the concepts and theories in relation to the game element is striking. The central question is 
how a specific game element can be designed to ensure an optimal achievement of goals (goal theory), an optimal level of difficulty (flow theory) or an optimal degree of autonomy (self-determination theory).

However, from the perspective of a non-definition of gamification, other concepts move into focus. Concepts, such as fun and enjoyment, also seem to make a valuable contribution to learner-teacher settings. The role of fun in learning seems undisputed, especially in early childhood $[22,32]$. There is also evidence for the importance of play in adulthood [13], the value of fun and humor in the workplace to increase creativity and productivity $[1,31]$ and to reduce stress [11, 20, 21].

For the specific context of higher education, recent research [67] has examined what is perceived by students as a joyful learning experience. A low level of stress caused by joy and fun in the learning environment was also mentioned. In addition, the results showed that a safe learning space in which mistakes can be accepted and made is an important element. With regard to the teacher, the enthusiasm of the teacher, a high level of expertise and the desire to teach were identified as important elements. On the relationship level, the results showed that students find it joyful to share experiences with other students in playful settings. A simple contact with the teacher-by meeting at eye level-was also perceived positively. The students' reports also highlighted the stimulating effects surprises, new elements and active learning. The effect of playful settings on students is an important aspect for curriculum planning, if the effects mentioned are intended, there is the possibility to trigger effects through playful elements (whatever they may look like). However, from a practical point of view, it must be clearly stated that the strategies mentioned in the study by [67] are not limited to playful settings. A recent study with a gamified learning environment-based on the non-definition of gamification-has the potential to invoke a joyful learning experience [56].

On a normative level, the question of whether learning in higher education should be fun is more controversial; for example, the use of fun and playful approaches is sometimes considered inappropriate on the grounds that they undermine the academic character of higher education [67]. The answer to this question should - and cannot-be given at this point, since, following the (non-)definition of gamification given here, a playful element cannot always be easily differentiated and identified. When broken down to the actual practice of teachers, this means that pedagogical action is characterized by the complexity and dynamics of the teaching-learning setting. There are many possibilities to achieve specific intended effects. The art lies in transferring the processes of weighing up learners (who-dimension), the teaching content (what-dimension), the possibilities of teaching didactics (how-dimension), one's own values (self-dimension) and the specific teaching context (context dimension) into situational practice (practice dimension) against the background of the intended pedagogical goals [58]. Gamification-as an ephemeral and unspecified tool-is thus a tool in the pedagogical toolbox.

\section{An Example of a Design Case}

We want to highlight the potential of the (non-)definition of gamification by describing a case design of a learning environment in the higher education context, that was designed based on reflections around (a) the high context-specificity of the teaching undertaken and (b) the (non-)visibility of the design elements - related to the non-definition of gamification and (c) the (non-)acceptance of the gamified elements by the students. The gamified concept was implemented in a psychology course of police recruits at a University of Applied Sciences in Germany. The concept centers around a potential crime that has taken place: the professor, who indented to teach psychology to the students was kidnapped (fabricated) as media reports showed. The substitution to the professor is Mr. Sepur, the person standing in front of the students. He asks the students to help him developing a reflexive toolkit for police recruits, who will help them becoming more reflective practitioners. His appearance and this behavior reflect what the students refer to as "like a student". However, he will help the students to grasp the content of the psychology curriculum within the course.

Concerning the context-specificity of the learning environment, planning reflections centered around the specific organizational culture of educating police recruits in Germany. Within the police training structures of young police officers, there seems to exist mechanics of command and obedience" (p. 247) with a simultaneous willingness to submit to it unreflectively [27] Tendencies, which Jasch [27] describes as the primacy of job-specific disciplining, appear to be the cause for this. The disciplining extends, on the one hand, to conformist behavior and on the other hand, to one's own body: tattoos, hairstyles, body jewelry and clothing. In view of this organizational-structural context within the police academy and the resulting problems for professional police practice $[27,53]$, the aim of the teaching concept was to create irritation within the courses to provide opportunities for reflection [5], specifically concerning different roles and stereotypes towards these roles.

With regard to the (non-)visibility of the design elements, the teaching concept based on reflections about the first author's (MS) own motivations and expectations towards joyful teaching and how this may influence the learning climate within the classroom [58]. Several years of teaching experience showed MS, that being able to creatively express himself during teaching provides him with experiences of 
fun and pleasure, which in turn was reflected in his commitment to the corresponding teaching-learning settings. MS was always highly motivated for the teaching, which he noticed especially when he had creative and playful possibilities for shaping his teaching. The playful elements during teaching (e.g. keynote design, humor, references to pop culture, different forms of classroom settings) were perceived as an enrichment by the learners-and also for himself. Concerning the planning of the learning environment, these reflections showed that the gamification of teaching is a joyful aspect for him personally; however, this does not mean that all learners have to feel this way nor that they have to be aware that he is implanting some gamified design elements. For example, the selection of comic-shirts matching the current story line as well as hiding Easter eggs on the keynote slides provided MS with feelings of fun and joy leading to a greater enthusiasm concerning the teaching [56]. Furthermore, concerning the narrative and the mechanics of the gamified learning environment, it was important in the design of the course that there are possibilities for gamification, but that students were allowed to decide for themselves to what extent they want to engage with it (if they are aware of the elements, e.g. Easter eggs).

This aspect of the potential (non-)acceptance of the gamified elements by the students was valued in the concept via the narrative and the mechanics. The procedures and rules of the (gamified) learning environment with reference to the goal that the students should achieve were introduced at the beginning of the course through the narrative of the kidnapped professor. The goal was to have the students work on a project that they would create in groups and provide-for those who want to engage with the narrative-a coherent story why this is important for them (and the kidnapped professor). In addition to the overall objectives, there were also smaller assignments (e.g. compiling a concept for deescalating behavior in a conflict; preparation for an examination, etc.), which were introduced as "additional tasks" via narrative elements. It was important to us, that all tasks (project work, additional tasks) could also be perceived and accepted from a non-gamified perspective, since they were the regular curriculum assignments. The decision whether and how to play_-and engage in the story-or not was thus left to the students on an individual level. However, even if students did not participate, they had the opportunity to experience other playful elements like keynote designs and the enthusiasm of their teacher.

A further description of the planning decisions and the evaluation of the teaching concept is presented elsewhere $[56,58]$. In short, the results showed that an overall positive resonance towards the teaching: for the teacher, the students who wanted to play and for those who decided not to engage with the narrative. However, the results also showed that the main positive effects were to elements, that were not directly related to the gamified environment (e.g. teacher enthusiasm), but seemed to be influenced by the approach. Finally, the narrative was important for some students, but not for others. Therefore, it was up to the students to decide if there has happened a crime (the kidnapping of the professor). Some students played, some did not—and they were not always aware that their teacher played. However, they were aware of experienced positive effects concerning the learning atmosphere within the course.

\section{Conclusion}

Gamification in educational contexts has potential. However, its use and its perceived usefulness and pedagogical value are dependent on what is understood as gamification. Based on our analysis that the distinction between play and games and what it is not is blurred and heavily dependent on the perspective, we argued for a non-definition of gamification. From our perspective, this would allow for the integration of initial controversial positions of the pedagogical value of gamification by opening up the space for exploration, experimentation and evaluation of a context-specific use of it.

Funding Open Access funding enabled and organized by Projekt DEAL.

\section{Compliance with Ethical Standards}

Conflict of interest MS declares that he/has no conflict of interest. SK declares that he/has no conflict of interest.

Ethical approval This article does not contain any studies with human participants or animals performed by any of the authors.

Open Access This article is licensed under a Creative Commons Attribution 4.0 International License, which permits use, sharing, adaptation, distribution and reproduction in any medium or format, as long as you give appropriate credit to the original author(s) and the source, provide a link to the Creative Commons licence, and indicate if changes were made. The images or other third party material in this article are included in the article's Creative Commons licence, unless indicated otherwise in a credit line to the material. If material is not included in the article's Creative Commons licence and your intended use is not permitted by statutory regulation or exceeds the permitted use, you will need to obtain permission directly from the copyright holder. To view a copy of this licence, visit http://creativecommons.org/licenses/by/4.0/.

\section{References}

1. Baldry C, Hallier J. Welcome to the house of fun: work space and social identity. Econ Ind Democr. 2009;31(1):150-72. https://doi. org/10.1177/0143831x09351215. 
2. Bandura A. Self-efficacy mechanism in human agency. Am Psychol. 1982;37(2):122-47. https://doi. org/10.1037/0003-066x.37.2.122.

3. Bandura A. Self-efficacy determinants of anticipated fears and calamities. J Pers Soc Psychol. 1983;45(2):464-9. https://doi. org/10.1037/0022-3514.45.2.464.

4. Bateman C. Playing work, or gamification as stultification. Inf Commun Soc. 2018;21(9):1193-203. https://doi. org/10.1080/1369118x.2018.1450435.

5. Brookfield SD. Teaching for critical thinking. Int J Adult Vocat Educ Technol. 2013;4(1):1-15. https://doi.org/10.4018/javet 2013010101.

6. Brookfield SD. Becoming a critically reflective teacher. San Francisco: Jossey-Bass; 2017.

7. Buck MF. Gamification von Unterricht als Destruktion von Schule und Lehrberuf. Vierteljahrsschrift Für Wissenschaftliche Pädagogik. 2017;93(2):268-82. https://doi.org/10.1163/25890581093-02-90000005.

8. Buckley P, Doyle E. Gamification and student motivation. Interact Learn Environ. 2014;24(6):1162-75. https://doi. org/10.1080/10494820.2014.964263.

9. Buckley P, Doyle E, Doyle S Game on! Students' perceptions of gamified learning. J Educ Technol Soc 2017;3(20):1-10.

10. Callois R. Man, play and games. Champaign: University of Illinois Press; 1961.

11. Charman S. Sharing a laugh: the role of humour in relationships between police officers and ambulance staff. Int J Sociol Soc Policy. 2013;33(3/4):152-66. https://doi.org/10.1108/0144333131 1308212 .

12. Chess $S$, Booth $P$. Lessons down a rabbit hole: alternate reality gaming in the classroom. New Media Soc. 2013;16(6):1002-17. https://doi.org/10.1177/1461444813497554.

13. Colarusso CA. Play in adulthood. Psychoanal Study Child. 1993;48(1):225-45. https://doi.org/10.1080/00797 308.1993.11822386

14. Córdova AG, Parreño, J. M., \& Pérez, R. C. (2017). Higher education students' attitude towards the use of gamification for competencies development

15. Cszikszentmihalyi M. Beyond boredom and anxiety: experiencing flow in work and play. San Francisco: Jossey-Bass; 1975.

16. Deterding S, Dixon D, Khaled R, Nacke L. From game design elements to gamefulness: defining gamification. ACM doi. 2011;10(1145/2181037):2181040.

17. Festinger L. A theory of social comparison processes. Hum Relat. 1954;7(2):117-40. https://doi.org/10.1177/001872675400700202.

18. Fischer H, Heinz M, Schlenker L, Münster S, Follert F, Köhler T (2017) Die Gamifizierung der Hochschullehre-Potenziale und Herausforderungen. In: Gamification und Serious Games. Springer, Fachmedien, pp 113-125

19. Hamari J, Koivisto J, Sarsa H (2014) Does gamification work? A literature review of empirical studies on gamification. In: 2014 47th Hawaii international conference on system sciences (HICSS), pp 3025-3034. https://doi.org/10.1109/hicss.2014.377

20. Holdaway S. Blue jokes: humour in police work. In: Humour in society: resistance and control. Palgrave: Macmillan; 1988. p. 106-22. https://doi.org/10.1007/978-1-349-19193-2_6.

21. Holmes J, Marra M. Having a laugh at work. J Pragmat. 2002;34(12):1683-710. https://doi.org/10.1016/s0378 $-2166(02) 00032-2$.

22. Hromek R, Roffey S. Promoting social and emotional learning with games. Simul Gam. 2009;40(5):626-44. https://doi. org/10.1177/1046878109333793.

23. Huang B, Hew KF. Implementing a theory-driven gamification model in higher education flipped courses: Effects on out-of-class activity completion and quality of artifacts.
Comput Educ. 2018;125:254-72. https://doi.org/10.1016/j.compe du.2018.06.018

24. Huizinga J (2015) Homo Ludens: Vom Ursprung der Kultur im Spiel. Rowohlt

25. Hung ACY. A Critique and Defense of Gamification. Journal of Interactive Online Learning. 2017;1(15):57-72.

26. Huotari K, Hamari J. Defining gamification: a service marketing perspective. ACM. 2012. https://doi.org/10.1145/2393132.23931 37.

27. Jasch M (2019) Kritische Lehre und Forschung in der Polizeiausbildung [Critical teaching and research in police training]. In: Howe C, Ostermeier L (eds) Polizei und Gesellschaft-Transdisziplinäre Perspektiven zu Methoden, Theorie und Empirie reflexiver Polizeiforschung, vol 2014. Springer, Fachmedien, pp 231-250. https://doi.org/10.1007/978-3-658-22382-3_10.

28. Juul J (2001) The repeatedly lost art of studying games. Game Stud 1(1). http://www.gamestudies.org/0101/juul-review/.

29. Koerner S (2009) Reflexion von Kontingenz und Kontingenz der Reflexion: Ein systemtheoretischer Kommentar. In: Lüsebrink I, Krieger C, Wolters P (eds) Schulinterne Evaluation. Impulse zur Selbstvergewisserung aus sportpädagogischer Perspektive. Sportverlag Strauß, pp 141-160

30. Koerner S, Staller MS (2020) Begrenzen für mehr Freiheit: Der Constraints-Led Approach als trainingspädagogische Perspektive auf das Design von Lehr-Lernsettings in- und außerhalb des Sports. In: Vogt T (ed) Vermittlungskompetenz in Sport, Spiel und Bewegung: Sportartspezifische Perspektiven. Meyer \& Meyer, pp 276-298

31. Lamm E, Meeks MD. Workplace fun: the moderating effects of generational differences. Employee Relat. 2009;31(6):613-31. https://doi.org/10.1108/01425450910991767.

32. Lieberman N. Playfulness: its relationship to imagination and creativity. New York: Academic Press; 1977.

33. Locke EA. Motivation through conscious goal setting. Appl Prev Psychol. 1996;5(2):117-24. https://doi.org/10.1016/s0962 -1849(96)80005-9.

34. Locke EA, Latham GP. Building a practically useful theory of goal setting and task motivation: a 35-year odyssey. Am Psychol. 2002;57(9):705-17. https://doi.org/10.1037/0003-066x.57.9.705.

35. Locke EA, Shaw KN, Saari LM, Latham GP. Goal setting and task performance: 1969-1980. Psychol Bull. 1981;90(1):125-52. https ://doi.org/10.1037/0033-2909.90.1.125.

36. Looyestyn J, Kernot J, Boshoff K, Ryan J, Edney S. Does gamification increase engagement with online programs? A systematic review. PLoS ONE. 2017;12(3):e0173403. https://doi. org/10.1371/journal.pone.0173403.

37. Luhmann N. The improbability of communication. Int Soc Sci J. 1981;1(23):122-32.

38. Lynch R, Mallon B, Nolan K. Mastering the puppets: criteria for pulling the strings in an alternate reality game. J Gam Virtual Worlds. 2013;5(1):23-40. https://doi.org/10.1386/jgvw.5.1.23_1.

39. Maslow AH. A theory of human motivation. Psychol Rev. 1943;50(4):370-96.

40. Matallaoui A, Hanner N, Zarnekow R. Introduction to gamification: foundation and underlying theories. In: Stieflitz S, Lattemann C, Robra-Bissantz S, Zarnekow R, Brockmann T, editors. Gamification, using game elements in serious contexts. Berlin: Springer; 2017. p. 3-18. https://doi.org/10.1007/978-3-319-45557-0_1.

41. McGonigal J (2011) Reality is broken. why games make us better and how they can change the world. Jonathan Cape, London

42. Morschheuser B, Hamari J, Werder K, Abe J. How to Gamify? A Method For Designing Gamification. In T. Bui (Ed.), Proceedings of the 50th Hawaii International Conference on System Sciences, pp. 1298-1307. https://doi.org/10.24251/hicss.2017.155

43. Pfeiffer A, Bezzina S, König N, Kriglstein S (2020) Beyond classical gamification: in-and around-game gamification for education. 
In: Busch C, Steinke M, Wendler T (eds) Proceedings of the 19th European conference on e-learning ECEL 2020

44. Pill S. Game play: what does it mean for pedagogy to think like a game developer? J Phys Educ Recreat Dance. 2013;85(1):9-15. https://doi.org/10.1080/07303084.2013.838119.

45. Raczkowski F, Schrape N. Game studies. In: Bell B, Hensel T, Rauscher A, editors. Game studies. Berlin: Springer; 2018. p. 313-29. https://doi.org/10.1007/978-3-658-13498-3_17.

46. Reeves B, Read JL. Total engagement: using games and virtual worlds to change the way people work and businesses compete. Cambridge: Harvard Business Press; 2009.

47. Richter G, Raban DR, Rafaeli S. Studying gamification: the effect of rewards and incentives on motivation. In: Reiners T, Wood LC, editors. Gamification in education and business. Berlin: Springer; 2015. p. 21-46. https://doi.org/10.1007/978-3-319-10208-5_2.

48. Rigby S, Ryan RM (2011) Glued to games: how video games draw us in and hold us spellbound. Praeger

49. Rogers R. The motivational pull of video game feedback, rules, and social interaction: another self-determination theory approach. Comput Hum Behav. 2017. https://doi.org/10.1016/j. chb.2017.03.048.

50. Ryan RM, Deci EL. Self-determination theory and the facilitation of intrinsic motivation, social development, and well-being. Am Psychol. 2000;55(1):68-78. https://doi. org/10.1037//0003-066x.55.1.68.

51. Sailer M, Hense JU, Mayr SK, Mandl H. How gamification motivates: an experimental study of the effects of specific game design elements on psychological need satisfaction. Comput Hum Behav. 2017;69:371-80. https://doi.org/10.1016/j.chb.2016.12.033.

52. Schöbel S, Janson A, Jahn K, Kordyaka B, Turetken O, Djafarova N, Saqr M, Wu D, Söllner M, Adam M, Gad PH, Wesseloh H, Leimeister JM. A Research Agenda for the Why, What, and How of Gamification Designs Results on an ECIS 2019 Panel. Commun Assoc Inf Syst 2020;46: 706-721. https://doi.org/10.17705 /1 cais.04630.

53. Schöne M (2011) Pierre Bourdieu und das Feld Polizei: Ein besonderer Fall des Möglichen. Verlag für Polizeiwissenschaft

54. Seligman MEP, Csikszentmihalyi M. Positive psychology: an introduction. Am Psychol. 2000;55(1):5-14. https://doi. org/10.1037/0003-066x.55.1.5.

55. Skinner H, Sarpong D, White GRT. Meeting the needs of the Millennials and Generation Z: gamification in tourism through geocaching. J Tour Futures. 2018;4(1):93-104. https://doi. org/10.1108/jtf-12-2017-0060.

56. Staller MS (2020) „Ich bin nur die Vertretung...“: Gamifizierung in der Psychologie Lehre an einer Hochschule der Polizei. Verlag für Polizeiwissenschaft
57. Staller MS, Heil V, Koch R, Koerner S. "Playing Doom"a design case in self-defense training. Int $\mathrm{J}$ Des Learn. 2020;11(2):9-16.

58. Staller MS, Koerner S (2021) Game on! Spielen in der polizeilichen Lehre. Lehre. Lernen. Digital (accepted for publication)

59. Stieglitz S. Gamification-Vorgehen und Anwendung. HMD Praxis Der Wirtschaftsinformatik. 2015;52(6):816-25. https:// doi.org/10.1365/s40702-015-0185-6.

60. Stieglitz S, Lattemann C, Robra-Bissantz S, Zarnekow R, Brockmann $\mathrm{T}$ (eds) (2017) Gamification: using game elements in serious contexts. Springer, Berlin. https://doi.org/10.1007/978-3-31945557-0

61. Subhash S, Cudney EA. Gamified learning in higher education: A systematic review of the literature. Comput Hum Behav. 2018;87:192-206. https://doi.org/10.1016/j.chb.2018.05.028.

62. Sutton-Smith B. The ambiguity of play. Cambridge: Harvard University Press; 2001.

63. Torrents C, Balagué N, Ric Á, Hristovski R. The motor creativity paradox: constraining to release degrees of freedom. Psychol Aesthet Creativ Arts. 2020. https://doi.org/10.1037/aca0000291.

64. Vegt N, Visch V, de Ridder H, Vermeeren A. Designing gamification to guide competitive and cooperative behavior in teamwork. In: Torsten R, Wood LC, editors. Gamification in education and business. Berlin: Springer; 2014. p. 513-33. https://doi. org/10.1007/978-3-319-10208-5_26.

65. Walther BK (2003) Playing and gaming: reflections and classifications. Game Stud 3(1). http://www.gamestudies.org/0301/walth er/.

66. Werbach K, Hunter D (2012) For the Win: How Game Thinking Can Revolutionize Your Business. Philadelphia: Warton Digital Press.

67. Whitton N, Langan M. Fun and games in higher education: an analysis of UK student perspectives. Teach Higher Educ. 2018;24(8):1-14. https://doi.org/10.1080/13562517.2018.15418 85.

68. Woodcock J, Johnson MR. Gamification: what it is, and how to fight it. Sociol Rev. 2018;66(3):542-58. https://doi. org/10.1177/0038026117728620.

Publisher's Note Springer Nature remains neutral with regard to jurisdictional claims in published maps and institutional affiliations. 